
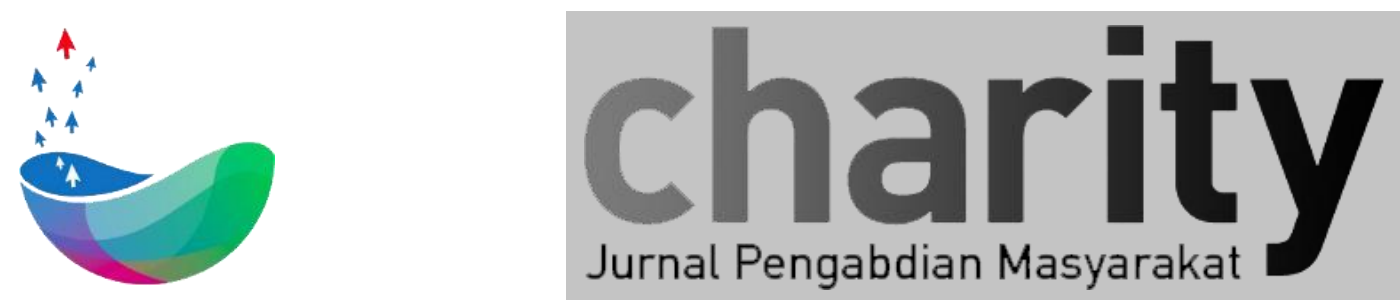

\title{
Penerapan Aplikasi Elektronik KMS Berbasis QR-Code di Posyandu Rumpun Bambu Kabupaten Bandung
}

\author{
Dadan Nur Ramadan ${ }^{1}$, Rohmat Tulloh $^{2}$, Ridha Muldina Negara ${ }^{3}$, Suryatiningsih ${ }^{4}$, Sari Dewi Budiwati ${ }^{5}$, Ratna \\ Mayasari ${ }^{6}$ \\ ${ }^{, 2}$ D3 Teknologi Telekomunikasi, Fakultas Ilmu Terapan, Universitas Telkom \\ ${ }^{3,6}$ Teknik Telekomunikasi, Fakultas Teknik Elektro, Universitas Telkom \\ ${ }^{4,5}$ D3 Sistem Informasi, Fakultas Ilmu Terapan, Universitas Telkom \\ *dadannr@telkomuniversity.ac.id, rohmatth@telkomuniversity.ac.id, ridhanegara@ telkomuniversity.ac.id, suryatiningsih@telkomuniversity.ac.id, \\ saridewi@telkomuniversity.ac.id, ratnamayasari@telkomuniversity.ac.id
}

\section{INFO ARTIKEL}

Diterima 18 Desember 2021

Direvisi 18 Januari 2022

Disetujui 20 Januari 2022

Tersedia Online 24 Januari 2022

\begin{abstract}
ABSTRAK
Posyandu memiliki peran dalam mendukung program pelayanan kesehatan masyarakat, diantaranya untuk manula, ibu hamil dan khususnya Balita. Dengan terjadinya pandemi covid-19 yang membuat adanya pembatasan pada kegiatankegiatan masayarakat, membuat kegiatan posyandu harus menyesuaikan dengan protokol kesehatan yang berlaku saat ini, diantaranya adalah pembatasan kegiatan dan mengurangi kerumunan. Salah satu kegiatan Posyandu adalah proses penimbangan berat badan balita dan pencatatannya pada sebuah dokumen, yaitu selembar kertas Kartu Menuju Sehat (KMS), dimana proses ini memerlukan waktu yang tidak sebentar dalam pencarian dokumen, serta proses pengisiannya yang masih manual, sehingga dapat menimbulkan kerumunan dan menyalahi protokol kesehatan. Salah satu upaya untuk menangulangi masalah tersebut, pada posyandu Rumpun Bambu diimplementasikan sebuah aplikasi elektronik-KMS (e-KMS) berbasis Quick Response Code (QR-Code) sebagai sarana untuk pendataan dan pencatatan balita. Penerapan aplikasi diharapkan dapat membantu mengurangi kerumunan di posyandu, serta dengan penambahan fitur QR Code pada aplikasi tersebut maka proses pencarian data balita dapat berjalan secara secara cepat dan tepat.
\end{abstract}

Keyword: Kartu Menuju Sehat, Posyandu, QR-

Code

Korespondensi:

Direktorat Penelitian dan Pengabdian Masyarakat, Universitas Telkom

Jl. Telekomunikasi No. 1, Terusan Buah Batu, Bandung, 40257

Indonesia

E-mail : ppm@telkomuniversity.ac.id

ORCID ID: 0000-0001-8377-7250

Penulis Pertama: Dadan Nur Ramadan

https://doi.org/xxx

Paper_reg_number xxx (C) The Authors. Published by Directorate of Research and Community Service, Telkom University. 
This is an open access article under the xxx license (https://creativecommons.org/licenses/xxx)

\section{Pendahuluan (Heading 1_Charity)}

Posyandu merupakan bagian dari Upaya Kesehatan Bersumberdaya Masyarakat (UKBM) yang dikelola dan diberdayakan oleh masyarakat dalam upaya untuk memperoleh pelayanan kesehatan dasar [1]. Upaya tersebut juga dilakukan oleh Posyandu Rumpun Bambu sebagai upaya memberikan pelayanan kesehatan masyarakat di sekitarnya.

Posyandu Rumpun Bambu, terletak di Kampung Cupu RT.02 RW.08, Desa Rancamanyar, Kecamatan Baleendah Kabupaten Bandung, Jawa Barat. Pada tahun 2021 posyandu Rumpun Bambu mewakili kabupaten Bandung sebagai peserta kompetisi Posyandu Nasional, yang memperlombakan seluruh kegiatan posyandu, diantaranya adalah fasilitas untuk balita, diantaranya pencatatan tumbuh kembang, pemberian vitamin dan imunisasi balita [2-3], yang dilakasanakan di posyandu Rumpun Bambu.

Aplikasi e-KMS yang sudah dibuat sebelumnya [4], ditambahkan dengan fitur Quick Response code (QR-Code). QR-Code adalah teknologi yang menggunakan gambar dua dimensi sebagai media untuk menyimpan data maupun kode biner [5], penambahan fitur ini dilakukan untuk meningkatkan kecepatan, akurasi pencarian data, serta meningkatkan keamanan data balita di posyandu.

\section{Metodologi}

Metode pelaksanaan penerapan aplikasi e-KMS berbasi QR-Code di Posyandu Rumpun Bambu Kabupaten Bandung, dilakukan melalui tahapan yang dibuat secara sistematis, dimulai dari tahap perencanaan, implementasi, sampai dengan evaluasi kegiatan, seperti yang diuraikan sebagai berikut:

\subsection{Persiapan}

Persiapan diawali dengan survei kepada beberapa kader posyandu, kemudian dilanjutkan dengan dilakukan survei awal terkait kebutuhan di lapangan, kemudian dibentuk tim yang terdiri dari dosen dan mahasiswa, yang berkolaborasi dalam menambahkan beberapa fitur tambahan yang akan disimpan kedalam aplikasi e-KMS berbasis android, penambahan tersebut salah satuya adalah implementasi QR-Code Generator dan Reader pada aplikasi e-KMS, seperti ditampilkan pada Gambar 1.

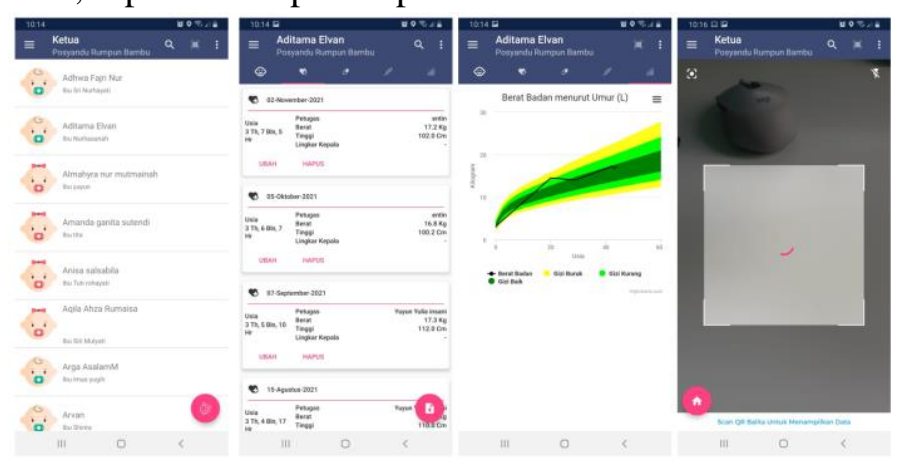

Gambar 1. Aplikasi e-KMS berbasis QR-Code 


\subsection{Pelaksanaan}

Implementasi dan pelatihan penggunaan aplikasi e-KMS berbasis QRCode dibantu oleh mahasiswa, dimana mahasiswa bertugas mengarahkan kader posyandu dalam proses instalasi pada masing-masing smartphone yang dimiliki oleh kader posyandu, pelatihan dalam memperguankan aplikasi eKMS dan QR-Code untuk pendataan balita ditujukan kepada para kader posyandu, dengan tujuan agar setiap kader dapat menggunakan aplikasi untuk kegiatan posyandu dan menambah point Kompetisi Posyandu Nasional, juga mengajarkannnya kepada ibu-ibu balita, seperti ditampilkan pada Gambar 2.

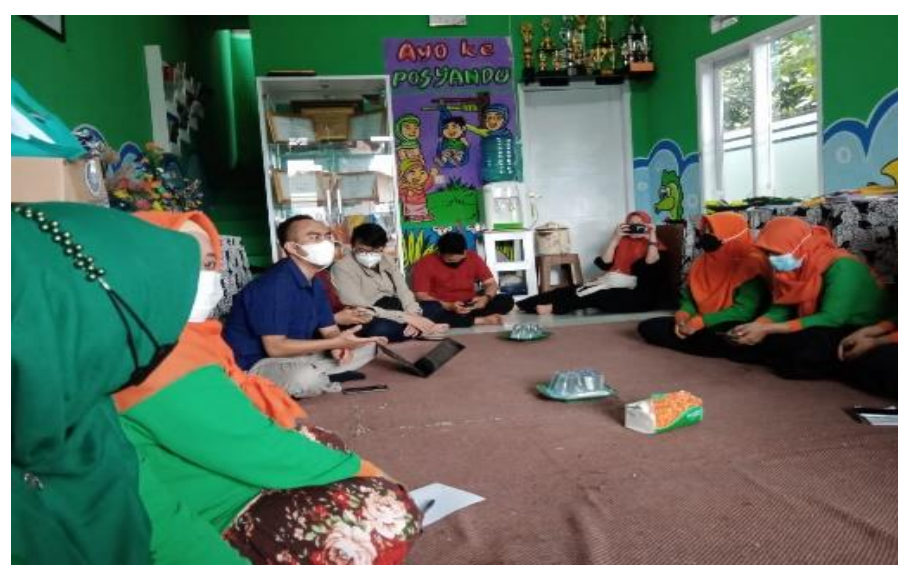

Gambar 2. Implementasi dan Pelatihan Aplikasi e-KMS untuk Kader Posyandu

Kemudian dilakukan proses troubleshooting dan Verifikasi data, yang di input pada aplikasi, dimana terdapat input data yang tidak valid atau tidak sesuai, kegiatan ini berlangsung selama dua bulan, untuk melihat proses adaptasi kader posyandu dalam menggunakan aplikasi e-KMS berbasis QRCode di lapangan, yang dimulai sejak proses instalasi, pencatatan, rekap data, proses troubleshooting dipelihatkan pada Gambar 3.

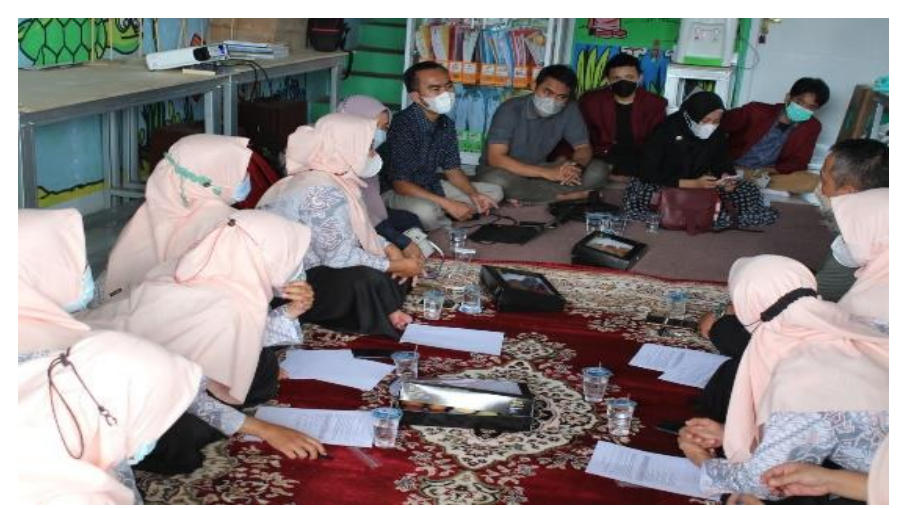

Gambar 3. Pendampingan Aplikasi e-KMS untuk Kader Posyandu

Pada proses ini ditemukan beberapa error pada aplikasi yang diselesaikan dengan update versi, juga adanya kesalahan yang terjadi karena input data, sehingga diperlukan pendampingan yang intensive. 


\subsection{Evaluasi Program}

Evaluasi perlu dilakukan di akhir pelaksanaan program, dengan tujuan untuk menentukan keberlanjutan program setelah selesai kegiatan dilaksanakan, juga dilakukan berdasarkan metode dan tahapan-tahapan kegiatan PKM sehingga hasilnya sudah dapat terlihat sejak awal dan langsung menjadi masukan untuk melakukan perbaikan karena akan menjadi input pada langkah dan tahap berikutnya, salah satunya dengan mengukur kepuasan masyarakat sasar dari kegiatan PKM dalam hal ini adalah orang tua balita. Pengukuran dilakukan melalui pengisian kuisioner terkait kepuasaan terhadap program kegiatan yang sudah dilakukan, kemudian mengukur penilaian pengguna terhadap aplikasi e-KMS melalui penilaian Mean Opinion Score (MOS). Penilaian dilakukan dengan memberikan penilaian terhadap beberapa poin seperti kemudahan, fungsionalitas, tampilan aplikasi dan sebagainya.

\section{Hasil dan pembahasan}

Dokumentasi kegiatan pelaksanaan Pengabdian kepada Masyarakat dimuat pada Youtube dangan link sebagai berikut; https://www.youtube.com/watch?v=U11IsaUumpY seperti ditampilkan pada Gambar 4.

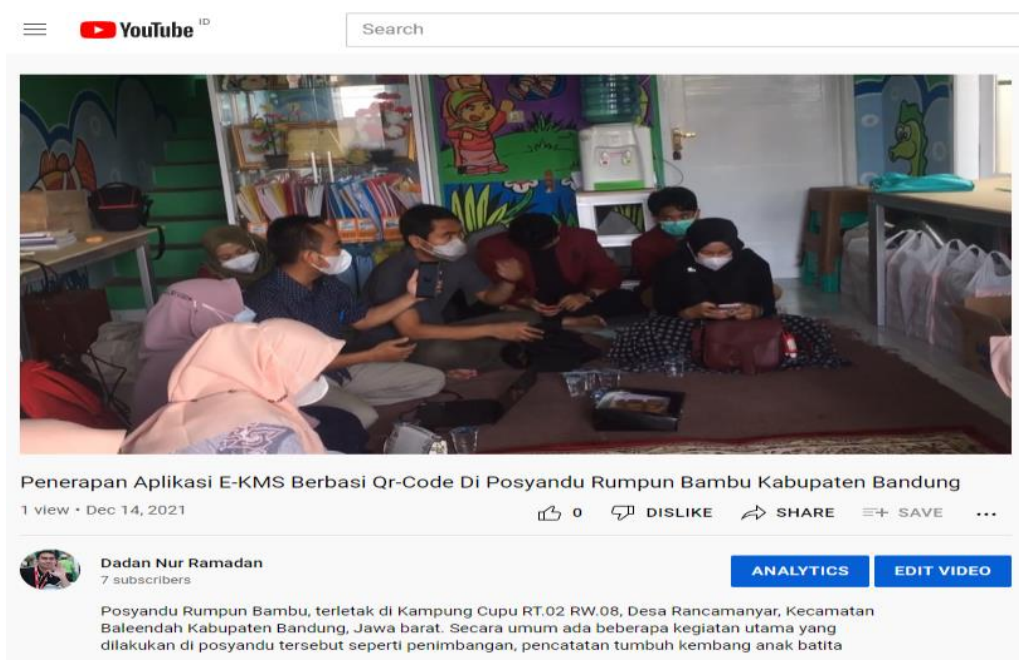

Gambar 4. Dokumentasi kegiatan Pengabdian Kepada Masyarakat di youtube

Untuk mengukur respon dan mendapatkan umpan balik dari mitra sasar terhadap kegiatan yang telah selesai dilakukan, maka peserta kegiatan diminta untuk mengisi kuesioner dengan format yang sudah ditentukan oleh Universitas Telkom, seperti ditunjukan pada tabel 1. 
Tabel 1. Rekap Hasil Feedback Peserta

\begin{tabular}{|c|c|c|c|c|c|}
\hline \multirow[b]{2}{*}{ No } & \multirow[b]{2}{*}{ Penilaian Terhadap Kegiatan } & \multicolumn{4}{|c|}{ Keterangan } \\
\hline & & $\begin{array}{l}\text { Sangat Tidak } \\
\text { Setuju }\end{array}$ & $\begin{array}{l}\text { Tidak } \\
\text { Setuju }\end{array}$ & Setuju & $\begin{array}{l}\text { Sangat } \\
\text { Setuju }\end{array}$ \\
\hline 1 & Sesuai dengan tujuan. & $0 \%$ & $0 \%$ & $0.09 \%$ & $90.91 \%$ \\
\hline 2 & $\begin{array}{l}\text { Sesuai kebutuhan masyarakat } \\
\text { sasarnya. }\end{array}$ & $0 \%$ & $0 \%$ & $0 \%$ & $100 \%$ \\
\hline 3 & $\begin{array}{l}\text { Waktu pelaksanaan kegiatan } \\
\text { mencukupi. }\end{array}$ & $0 \%$ & $0 \%$ & $0.09 \%$ & $90.91 \%$ \\
\hline 4 & $\begin{array}{l}\text { Dosen dan mahasiswa bersikap } \\
\text { ramah, cepat dan tanggap } \\
\text { membantu selama kegiatan. }\end{array}$ & $0 \%$ & $0 \%$ & $0 \%$ & $100 \%$ \\
\hline 5 & $\begin{array}{l}\text { Masyarakat menerima dan } \\
\text { mengharapkan kegiatan di masa } \\
\text { yang akan datang. }\end{array}$ & $0 \%$ & $0 \%$ & $0 \%$ & $100 \%$ \\
\hline
\end{tabular}

\section{Kesimpulan}

Meskipun pada pelaksanaanya terdapat beberapa error pada aplikasi yang dapat diselesaikan dengan dilakukan update versi, juga adanya kesalahan yang terjadi karena input data, sehingga diperlukan pendampingan yang intensive, namun kegiatan dapat terlaksana dengan lancer dan sukses, hal tersebut dilihat berdasarkan hasil feedback pengabdian masyarakat yang tim universitas telkom lakukan tujuan pengabdian masyarakat untuk Penerapan Aplikasi e-KMS Berbasi Qr-Code Di Posyandu Rumpun Bambu, Kabupaten Bandung. Dari sebelas perwakilan kader posyandu mengisi kuesioner feedback, sebesar 9,09\% menyatakan setuju dan 90,91\% sangat setuju bahwa kegiatan sesuai dengan tujuan dan waktu pelaksanaan kegiatan mencukupi kebutuhan, kemudian $100 \%$ sangat setuju bahwa kegiatan pengabdian kepada Masyarakat sesuai dengan kebutuhan mitra, serta tim pelaksana dari Universitas Telkom yang terdiri dari dosen dan mahasiswa bersikap ramah, cepat dan tanggap selama kegiatan berlangsung. Masyarakat sasar juga mengharapkan kegiatan serupa dari Universitas Telkom sebagai solusi dari berbagai masalah yang ada. 


\section{DAFTAR PUSTAKA}

[1] Kementrian Kesehatan RI, Buku Pegangan Kader Posyandu, Jakarta, Pusat Promosi Kesehatan, 2012.

[2] Kementrian Kesehatan RI, Panduan Orientasi Kader Posyandu, Jakarta, Direktorat Promosi Kesehatan dan Pemberdayaan Masyarakat, 2019.

[3] Kementrian Kesehatan RI, Panduan Pelayanan Kesehatan Balita Pada Masa Tanggap Darurat COVID-19, Direktorat Kesehatan Keluarga, Direktorat Jenderal Kesehatan Masyarakat, Kementerian Kesehatan, 2020.

[4] L. F. Freitas, A. R. Nogueira, and M. E. V. Melgar. "Data Validation System Using QR Code and Meaningless Reversible Degradation", Int. Conf. Appl. Electron., vol. 2019-Septe, pp. 3-6, 2019.

[5] Tulloh, R., Ramadan, D.N., \& Gusnadi, D. (2020). Aplikasi e-KMS untuk Pendataan dan Rekapitulasi Tumbuh Kembang Balita di Posyandu Mekar Arum 18. Jurnal Panrita Abdi, (4)2, 215 - 224. 